\title{
Strategies to Implement Effective Personnel Evaluation System to Assess the Public Servants of Bangladesh
}

\author{
Mohammad Showkat Ali ${ }^{1}$ \\ ${ }^{1}$ Graduate School of Economics, Yamaguchi University, Yamaguchi, Japan \\ Correspondence: Mohammad Showkat Ali, Graduate School of Economics, Yamaguchi University, Yamaguchi, \\ Japan. E-mail: showkat25bcs@gmail.com
}

Received: July 18, 2013 Accepted: July 29, 2013 Online Published: September 29, 2013

doi:10.5539/par.v2n2p80 URL: http://dx.doi.org/10.5539/par.v2n2p80

\begin{abstract}
Personnel evaluation system is a significant tool which manipulates efficiency of civil servants. Researchers have found that effectiveness of personnel evaluation system of Bangladesh is not satisfactory compared to expectancy. Unproductive personnel evaluation system of Bangladesh is liable for insufficient efficiency of civil servants. This study will emphasize the realization of effective personnel evaluation system to ascertain accountability and the enrichment of efficiency of civil servants. Running personnel evaluation system of Bangladesh is unskilled to employ the ability of civil servants, to give appropriate ways to perform work by civil servants, to guarantee proper utilization of working time of civil servants, and to produce the sense of belongingness among civil servants. It has no alignment strategy with organizational goals and objectives. Armstrong M. \& Baron A. (2005) have stated that the success of personnel evaluation system notably depends on the alignment with clear organizational goals which are produced from organizational evaluation. Organizational performance indicators assist to create clear and unembroidered performance indicators for civil servants. Advanced and internal performance indicators of organization strengthen alignment strategy. Alignment strategy inspires personnel to move in the same way with the organization to accomplish common goals. Bangladesh needs strategies to ascertain alignment between personnel evaluation system and organizational goals.
\end{abstract}

Keywords: personnel evaluation system, organizational evaluation system, organizational goals, alignment of personnel evaluation system and organizational goals

\section{Introduction}

\subsection{Back Ground of the Problem}

Personnel evaluation system is a means to maintain high competent and efficient civil servants (Mohammad Ashraful Haque -2012). Public sectors must preserve high productivity, efficiency, and effectiveness for accelerating economic growth and development. Public agencies should uphold organizational and human capital fullness for the progress. The rise of industrialized humanism has driven human capital as the central key for the advancement of the country. The achievements of human capital for the organizations are named as performance.

Performance evaluation is a way of assessing the achievements of employees for the organization. Robert Owen had launched systematic performance evaluation in his Lanark textile mills during the 1800s. In accordance with his appraisal system, supervisor had put a portion of timber in front of each employee's machine each day marked with a diverse color, which had expressed the judgment of supervisor of performance of the previous day of that worker (Newstrom \& Davis, 1993). In the beginning of the twentieth century, F.W. Taylor has introduced the scientific management of evaluation. This system has stressed the utilization of quantitative methods to evaluate the performance of work. Despite private sectors are the innovators of performance evaluation system, the contemporary performance evaluation system has adept in the public sector (Daley, 1993). Performance evaluation system as a device of efficiency has introduced in the public sector under the ripple of New Public Management (NPM) in the late 1970s (Daley, 1993). It is a performance based evaluation technique. The assumption is that the performance management of public sector will follow the techniques of private sectors pursued for performance management. Many countries reviewed their personnel evaluation system in order to build efficient civil servants. Bangladesh is not separate from the demand such performance based evaluation of civil servants. The wave of this reform wants an effective personnel evaluation system in Bangladesh. 
Is personnel evaluation system of Bangladesh operating well? Mohammad Ashraful Haque (2012) has stated that the existing incompetence of civil servants of Bangladesh confers the sense that current personnel evaluation system is poorly functioning. He also has stated that the current personnel evaluation system considerably wants of validity and reliability, and as a result, it is imperfect in accomplishing the objectives. He has also affirmed that the ineffective personnel evaluation system of Bangladesh has reduced self-confidence, decreased efficiency of civil servants, and diminished sense of belonging among civil servants. Monem, M., Osman, F., \& Nuruzzaman, M. (2009) have stated that the indicators of existing personnel evaluation system have hardly something to do with assessing the performance of a civil servant. They have also said that the existing system is not based on perfect standard, most often the injustice and unfairness of evaluator come into play, which at last goes against the purpose of evaluation, and in general, it depends on the wishes of the evaluator. They have added that the comment part of existing evaluation is written by evaluator in subjective way, there are no guidelines for writing the comments, and as a result, the evaluators make confusing comments.

Mohammad Ashraful Haque (2012) has stated that the running personnel evaluation system of Bangladesh significantly lacks soundness; consequently administrative decisions like promotion, posting, and disciplinary action based on the current evaluation system will probable to go against fairness. He has also added that reliability in the personnel evaluation system is also low due to non-standardization of the performance indicators. He has also affirmed that since current personnel evaluation does not focus on the job description and does not permit any reply concerned evaluation except the adverse comment; it has no relevance to career planning and performance improvement. So the effectiveness and efficiency of the current personnel evaluation system is disputable. As imperfect personnel evaluation system, the current system might generate more troubles than solution. Mohammad Ashraful Haque (2012) has discussed the reliability, validity, and effectiveness of current personnel evaluation system, but how the current personnel evaluation system would be effective is absent in his study.

\subsection{Importance of the Problem}

Civil servants are truly influential in decision making and development implementing procedure of Bangladesh. There are two ladders of administration; those are field administration and central government. In central government, the role of civil servants is to assist political government in policy formulation and decision making. In field administration, the civil servants implement policy, deliver government service, execute development project, and ascertain public security and safety. Civil servants have played a critical role both in policy formulation and implementation in Bangladesh.

Though civil servants are dominant in administration of Bangladesh, people and experts perceive the performance and efficiency of civil servants as inadequate compared to public expectation. The performance and efficiency of public sectors is the accumulation of performance and efficiency of civil servants. To know the status of performance and efficiency of civil servants at first has to be familiar with the status of performance and efficiency of public sectors. Public perception is quite hostile about the performance and efficiency of public sectors. In accordance with a survey conducted by "The Mahbub ul Haq Human Development Centre" on "Human Development in South Asia: The crisis of Governance" in 1999, sixty four percent of people feels that public sectors have failed to protect their rights. The survey has also found that the performance of public agencies is rather miserable in Bangladesh, and the quality of services of major public sectors is not up to the mark. In 1996 World Bank has mentioned the image of mass people of Bangladesh about the public sector service that it is unaccountable and inefficient. Zafarullah and others (1997) have mentioned that in Bangladesh public satisfaction with necessary public services is quite low and common people are quite unhappy with the unresponsive behavior of public servants. In 1996 World Bank has observed that public satisfaction on health, education, and electricity supply is particularly negligible.

I have assembled "Worldwide Governance Indicators" of nations mentioned in "Table 1" to know the status of efficiency and performance of civil servants of Bangladesh comparison to some OECD countries, Indian, and Indonesia. Governance indicators signify the efficiency and performance of government. The efficiency and performance of civil servants reflects the efficiency and performance of public sectors.

According to "Table 1", members of OECD countries are outperforming. Also, the performance and efficiency of civil servant of Bangladesh is very insignificant compared to Indonesia and India. Personnel evaluation systems of OECD countries are well recognized and all of them have established effective performance evaluation systems. Even Indonesia and India have also launched more distinct and separated performance measurement systems and also gained better than Bangladesh. I do not argue that such differences in performance are the function of the difference between their respective personnel evaluation systems. However, we can perhaps say that having a better personnel evaluation system is one important variable of the performance of civil servants. 
Table 1. The importance of modifying personnel evaluation system in Bangladesh (Percentile Rank (Note 1))

\begin{tabular}{lccccc}
\hline Country & $\begin{array}{c}\text { Voice \& } \\
\text { Accountability }\end{array}$ & $\begin{array}{c}\text { Government } \\
\text { Effectiveness }\end{array}$ & $\begin{array}{c}\text { Regulatory } \\
\text { Quality }\end{array}$ & $\begin{array}{c}\text { Rule of } \\
\text { law }\end{array}$ & $\begin{array}{c}\text { Control of } \\
\text { corruption }\end{array}$ \\
Japan & 82 & 89 & 81 & 88 & 92 \\
Sweden & 99 & 99 & 97 & 100 & 99 \\
Luxembourg & 98 & 94 & 96 & 98 & 95 \\
Finland & 97 & 100 & 99 & 100 & 98 \\
Australia & 95 & 96 & 95 & 95 & 96 \\
United Kingdom & 92 & 92 & 97 & 95 & 90 \\
Canada & 94 & 97 & 96 & 96 & 97 \\
United States & 87 & 90 & 90 & 91 & 86 \\
Indonesia & 48 & 48 & 40 & 31 & 27 \\
India & 59 & 55 & 39 & 55 & 36 \\
Bangladesh & 38 & 22 & 22 & 27 & 16 \\
\hline Source & & & & &
\end{tabular}

Source: The author compiled the data from World Governance Indicators 2010

The efficiency and performance of civil servants compared to some OECD countries, Indonesia, and India signify the reforming of personnel evaluation system in Bangladesh. The personnel evaluation system is essential for preserving a standard of civil servants. Nevertheless, an ineffective personnel evaluation system can bring many troubles including abridged morale, diminished productivity, and weakened sense of belonging (Somerick, 1993). Therefore, constant development in the personnel evaluation system is a prerequisite for high performing organizations.

That is why; I have preferred to identify ineffective personnel evaluation system as the problem in this study and to explore the solutions accelerating the civil servants to enhance efficiency. Mohammad Ashraful Haque (2012) has stated that the efficient and effective personnel evaluation system is a prerequisite for high performing organizations and civil servants. Lawler and others (1984) have said that an effective evaluation system ensures the practice of civil servants' ability, working time, creativity, and sense of belongingness.

\subsection{Relevant Literature}

The concept of performance measurement system has developed over the last two decades as an incorporated process which integrates goal-setting, performance evaluation and development of a combined and consistent structure with the precise aim of aligning employees' performance goals with the organization's larger goals (Dessler, 2005; Williams, 2002). An integrated evaluation system realizes organisational goals through better performance and increases the abilities of personnel and organizations (Armstrong \& Baron, 2005).

David Orr (August 31, 1993) has stated that integration between organizational and personnel evaluation system is the best among alternatives performance measurement systems in public sectors. This model persuades teamwork and organization performance and gives the focus on the alignment of personnel evaluation system and organizational goals. He has also stated that organizational evaluation system supports to attain the accountability of the organization and also gives the information to civil servants and organizations on goals of organization they require to enhance the performance of individual, team, or organization. Performance measurement system should apply equally well at the employee and organizational level. He also added that advanced and unambiguous organizational goals, undistorted performance metrics for civil servants aligned with organizational goals, and transformation of organization's performance into personal performance are the basic principles of personnel evaluation system. He has also affirmed that one of the vital reasons of fractioning organizational performance into personnel performance evaluation system is to encourage employee meeting of organizational goals and the enhancement of organization performance. Jay R. Schuster and Patricia K. Zingheim (1992) have stressed the significance of bringing organizational goals into front position of organizational and personnel evaluation system.

Carol Atkinson and Sue Shaw (2006) have stated that here are a number of principles underlying for effective personnel evaluation system. Firstly, it is a planned process that is aligned to the organizational wider goals and objectives. Secondly, it is comprehensive in nature that is not only aligning organisational goals with personnel goals but also linking collectively diverse aspects such as personnel management, personnel advancement, personnel reward, and organisational development. Thirdly, it is concerned with performance enrichment in order to accomplish both personnel and organisational efficiency. Fourthly, it is communicating and accepting in nature 
and it is the fact that performance measurement is based on an agreement between organization and personnel, a mutual understanding and ongoing exchange of ideas about personnel goals and values estimated and the competencies required, together with an enjoyment of the organizational goals and objectives.

Roland F. Speklé \& Frank H. M. (2009) have stated that an effective personnel evaluation system must have alignment with organizational goals having clear and undistorted targeted goals and performance metrics and recognition of personnel contribution in the organizational achievements. They have also added that effective personnel evaluation system requires some principle (1) that organizational goals should be specified unambiguously in advance, (2) that organization must be competent to find out undistorted performance indicators that offer inducements and rightly align with organizational goals, and (3) that authority of organization must know how the achieved organizational goals will be factored into personnel evaluation system.

Luxembourg presidency of European Union (June 2005, page 18) has mentioned that in order to ensure the success of government and human resource, human resource strategy must be aligned with the organizational strategy effectively. EU has also mentioned that strategies of human resources must be aligned with the governmental strategies and support organizational changes. EU has also affirmed that human resource strategies are actively supporting organizational strategies for effective public administration. Hellenic (Greek) presidency of the European Union, Ministry of interior, public administration \& decentralization of Greek on June 08-09, 2003 has conducted a survey, and this survey has found that alignment between human resources and organizational strategies is the significant factor for successful personnel evaluation system.

David Orr (August 31, 1993) has also stated that effective alignment between public servants and organization evaluation strategies generates a strong teamwork and effective working relationships. In this system, each civil servant devoted to a team to achieve the organizational goals and objectives. S. Rynes, K. Brown, and A. Colbert (2002) have conducted a research, and they have found that an evaluation system having clear and specific organizational goals increases performance of human resource and organization. Their findings have recommended that evolution system of the employee must have clear goals as well as organizational evaluation system for better performance. International Labour Organization (ILO) (2009) has said that a variety of personal factors affects the agency's performances; alignment is essential demand between personnel evaluation and agency's achievements. Agency's achievements should carry a considerable weight in personnel appraisal system.

\subsection{Assumptions and Research Design}

Theoretical consensus is that effective personnel evaluation system wants some requirements. It must have alignment with organizational goals, and it should get assistance from organizational evaluation system to identify clear and unambiguous targeted goals, and it has to receive undistorted performance metrics from organizational evaluation system. From theoretical argument the assumptions are:

Assumption 01: An effective personal evaluation system aligns with clear and explicit organizational goals.

Assumption 02: Organizational evaluation system assists to get clear and unambiguous targeted goals and undistorted performance metrics.

Bangladesh desires comprehensive pragmatic study to assess the efficiency of present personnel evaluation system and the ways of reforms. Running personnel evaluation system requires empirical research to measure the competence of preserving the features of an effective evaluation system. I will explore two significant questions to determine the potential effectiveness and efficiency of personnel evaluation system in Bangladesh and these research questions are;

(1) The existing personnel evaluation system of Bangladesh is not effective, is it?

(2) If not, what reform initiatives are needed to make it effective?

Many researchers have made the study on public administration and civil servants of Bangladesh. They have researched on various aspects of personnel evaluation system of Bangladesh. The researchers have identified that current personnel evaluation system is not effective. But they have ignored to find out the causes of ineffectiveness of present personnel evaluation system in particulars, deeply, and distinctively. They have assessed the efficacy of running personnel evaluation system from in general stance, but disregarded to give specific ways and techniques to resolve this ineffectiveness. Hence, what specific ways and techniques needed to take reform initiatives of personnel evaluation system to secure the effectiveness is so far been ignored in previous researches regarding personnel evaluation of Bangladesh. I will explore the causes of ineffectiveness of current personnel evaluation system in details and distinctively and will discover the techniques and ways to reform the present personnel evaluation system to ascertain the efficiency and effectiveness. 


\section{Methodology of the Study}

This study bases on secondary data. I will make a comparative analysis on performance evaluation system of four nations and identify the factors of success of personnel evaluation system. I have selected performance evaluation system of Japan, Australia, Finland, and Indonesia to discover influential factors that contribute to the effective personnel evaluation system. Why is performance evaluation system of Japan, Australia, Finland, and Indonesia selected to analyze? The performance and efficiency of Japan is exemplary for Bangladesh. Furthermore, public administration of Bangladesh has a good relation with the counterpart of Japan. The performance and efficiency of public sector of Australia is high. Furthermore, many Bangladeshi young official and students are receiving higher degree from Australia. Australia's public administration is very well known to us. Finland's performance is also good. All European countries have signed Common Assessment Framework (CAF) 2006, and under this agreement, all member countries of EU should implement organizational and personnel evaluation system. Practices of all EU members are alike. Otherwise, European Union is the largest development partner of Bangladesh. So exercising the experience of EU will encourage donors in Bangladesh. I have selected Finland among EU countries. Indonesia is the South-East Asian and neighboring country of Bangladesh. Culture and administration of Indonesia has many similarities with Bangladesh. It reformed public administration few years ago. It is developing country as like Bangladesh. Here, dependent variables are efficiency and performance of civil servants and independent variables are clear and unambiguous organizational goals, organizational evaluation system, undistorted performance metrics, and alignment of personnel evaluation system and organizational goals. Efficiency of civil servants is the ability to accomplish the targeted goals. Performance of civil servants is the accomplished works. Organizational goals are the mission and vision of the government.

\subsection{Roadmap of Subsequent Subsections}

Subsequently this paper will convey contemporary personnel evaluation system and its features of Bangladesh, comparative analysis and case studies among personnel evaluation systems of Japan, Australia, Finland, and Indonesia, results, and discussion. In part of contemporary personnel evaluation system, I will talk about present personnel evaluation system and its features of Bangladesh. In comparative analysis and case studies, I will analyze the performance evaluation system of four nations. Here, I will highlight the factors of success of personnel evaluation system. In the 'result' section of the paper, I will gather the findings from practical evidences and theories. In the 'discussion' part of the paper, I will explore the recommendations for reforming personnel evaluation system of Bangladesh to be effective.

\subsection{Contemporary Personnel Evaluation System and its Features in Bangladesh}

Present personnel evaluation system commenced in the Pakistan regime and preserved maintaining minor amendment to measure performance of civil servants. Organizational evaluation system is not yet practiced. In personnel evaluation system, government uses a confidential report, and its official name is Annual Confidential Report (ACR). This confidential report measures the performance of all civil servants of Bangladesh. The confidential report conveys twenty five indicators and all indicators are personal traits. Performance indicators of existing personnel evaluation system are common for all civil servants in Bangladesh. Performance indicators have no alignment with organizational goals and job description. Performance indicators are qualitative in nature. Superior officer is the assessor, and the re-assessor is the immediate superior of assessor. It is extremely confidential. It has no job description, workload analysis, alignment with pay scale, and integration with promotion and posting. It also contains subjective comments. Assessors and re-assessors are diversified numbers.

\subsection{Comparative Analysis and Cases Studies}

Effective public administration is an essential tool for better performances and efficiency of public sectors. Effectiveness of public administration is the outcome of effective evaluation system to some extent. For the effective administration, some states have implemented performance evaluation system in personnel as well as organizational level. Most of the OECD countries have implemented performance evaluation system at organization and personal level. Personnel evaluation systems of those countries have integration with organization goals. Theory advocates that each state must have performance evaluation for personnel along with organization and be aligned with organizational goals. NPM suggests that organizational evaluation system must communicate with personnel evaluation system. It emphasizes to implement effective personnel management in public organization and must have a connection with organizational goals. I have integrated performance evaluation systems of Japan, Australia, Finland, and Indonesia in analysis.

\subsubsection{Japan's Case}

Japan has introduced a new personnel assessment program in 2009 to evaluate personnel performance in public 
sectors. It has exercised organizational and personnel evaluation system. The new personnel evaluation system comprises of competency evaluation and performance evaluation. Competency evaluation system evaluates the ability of a civil servant to perform duties during the appraisal period. Others items of competency evaluation are ethics, coordination, operational management, leadership in the organization, and human resources development. Performance evaluation system evaluates the degree of realization of the targeted goals. Ministries set and notify these goals to civil servants in advance as their role. Under this evaluation, unit chief of head quarter/ the Cabinet Office/Ministries place the goals of public employee. Those organizations set three to five goals for each employee. Goals set for the civil servants come from organizational goals.

Organizational evaluation is the policy evaluation system. It is the compilation of policies, programs, and projects evaluation. Each ministry has own system to evaluate their policies, programs, and projects. It evaluates the accomplishment of policies, programs, and projects. Each ministry conducts evaluation of performance by their own standards and indicators.

Organizational evaluation system produces information on clear organizational goals and undistorted performance metrics. It assists the alignment strategy between personnel evaluation and organizational goals. Policies, programs, and projects of government help to identify the targeted goals of personnel. Personnel evaluation system uses the information of clearly recognized organizational goals in organizational evaluation. Ministries set apparent goals for each civil servant in the interview. Interviews influence the contribution of each civil servant in organizational goals. Ministries acknowledge the contribution of each civil servant in the aggregate achievements of the organization at the end of the year. Those are techniques to measure the extent of participation of civil servants in organizational achievements. First interview assures the alignment strategy of evaluation of civil servants and organizational goals, and last interview estimates the achieved degree of alignment.

Discharging organizational accountability to civil servants reflects the efficiency and performance of civil servants. Organizations constantly strive to make civil servants more accountable through delegating goals. The assurance of civil servants' accountability attains the accomplishment of organizational accountability. As a result, aligning organizational goals with the targets of civil servants brings the civil servants under accountability. Alignment strategy of targets of civil servants and organizational goals ensures the measurement of civil servants' contribution for the attainment of organizational goals by means of personal evaluation. Ministries set the targeted goals of civil servants complying with the ability of civil servants. Interviews facilitate to give directions to civil servants to perform the work efficiently and effectively. Since the ability complies with the targets, civil servants have to use time properly to complete the work within time. Since, ministries delegate the discretion of disposition, and they recognize their contributions to organizations, civil servants feel a sense of belongingness in the mind.

\subsubsection{Australia's Case}

Australia Public Service Commissioner's Directions-1999 has mentioned that each organization is indebted to apply personal and organizational evaluation system. Each agency has to perform personnel evaluation system to promote the worth of its civil servants. Personnel evaluation system has relation with salary movement and organisational goals. It is distinctive and has independent performance indicators of civil servants for each agency. Organizational evaluation system of each agency measures the achieved organizational goals. It has clear and undistorted performance indicators. It clarifies the organizational goals and objectives. Personnel evaluation system generates its indicators using organizational performance indicators.

Personnel evaluation system measures the performance of civil servants taking into consideration their contribution in organizational success. Goals and performance indicators of this evaluation system come from organizational goals. Organizational evaluation system helps to make a liaison of performance of civil servants with organizational performance and salary. Both evaluation of civil servants and organizations are to measure the achievements of organizational goals. Performance indicators of both are following organizational goals.

Strategy of organizational evaluation is to secure organizational accountability. Organizations are accountable to achieve organizational goals, and they delegate their accountability to civil servants. Civil servants are liable to achieve organizational goals, and their evaluation system considers it. Ministries fix the targets of civil servants, which generate a sense of belongingness. Ministries allocate jobs to civil servants following their ability. Organization directs its personnel to achieve organizational goals. Intensive supervision of organizations over personnel and pressure to complete targets within the time limit ensure the tightened use of working time. Organizations recognize the performance of civil servants in organizational performance evaluation success and links with pay scale. Furthermore, discretion to discharge duties of civil servants generates the sense of belongingness. 


\subsubsection{Finland's Case}

Macro, Meso, and Micro level contracts are the performance evaluation systems of Finland (Uusikylä P. \& Virtanen P. - 1999). Macro and meso level contracts are for actualization of organizational goals. Those contracts assist to measure organizational performance. Micro level contract is for materialization of goals of civil servants and works to measure performance of civil servants. The cabinet and parliament of Finland executes the macro contract. Parliament of Finland measures the performance of ministries using macro contract. Meso level contract is the navigation between the ministries and their subordinate agencies. Meso contract helps to measure the performance of subordinate agencies. Subordinate agencies and civil servants perform the micro contract. Aims of subordinate agencies are complying with the targets of civil servants and civil servants commit for achieving the targeted results by this contract.

Macro contract arranges the alignment between targets of parliament or cabinet and performance evaluation of ministries. Meso contract ensures the alignment between ministerial goals and performance evaluation of subordinate agencies. Micro contract establishes the alignment between goals of sub-ordinate agencies and performance evaluation of civil servants. Alignment of goals of sub-agencies and civil servants helps to measure the performance of civil servants in realizing agency goals. The goals of parliament or cabinet are downward up to civil servants.

Ministries are liable to parliament to accomplish targets of cabinet. Ministries delegate the responsibilities of accomplishing targets of the cabinet to sub-ordinate agencies. Subordinate agencies hand over the responsibilities of accomplishing targets of the cabinet to civil servants. Civil servants are the final actors to realize the targets of cabinet. Civil servants are the marginal accountable unit for the accomplishment of government goals. Accountability of civil servants compels each staff to meet the objectives or work in a collaborative and holistic way. Micro level contract between subordinate agencies and civil servants helps to allocate the workload to civil servants and provides procedures to civil servants to perform duties and responsibilities. Subordinate agencies allocate the works to civil servants in accordance with the ability that certifies the proper utilization of ability of civil servants. The procedures of micro contract to perform duties enable civil servants to execute work properly. Ability based works distribution compels civil servants to use working time properly to accomplish the work within time. Delegation of authority to civil servants to perform duties and responsibilities generates an ownership feeling of responsibility and authority in the mind of civil servants.

\subsubsection{Indonesia's Case}

Indonesia recently has done public administration reform to ensure accountability and transparency of public administration and civil servants. It has evaluation system of civil servants and organizations. Institut Pemerintahan Dalam Negeri (Institute of Public Administration) monitors the organizational evaluation system. Each agency has a performance accountability report termed as organizational evaluation. This report contains an overview of the government performance accountability picture. It holds information about the accomplishment of government objectives and goals. Personnel evaluation system is a periodic assessment of implemented work. The purpose of personnel evaluation is to determine the success and failure of civil servants and weakness and strength possessed by civil servants. Along with work assessment, personnel evaluation system also assesses some personal traits that have impacts on performance of civil servants and these include loyalty, job performance, responsibility, obedience, honesty, cooperation, initiatives, and leaderships. Work assessment of personnel evaluation system helps to know the contribution of civil servants in organizational achievements.

Personnel evaluation system has relation with organizational goals through job analysis and workload analysis. Job analysis is a way to identify the activities to be performed to realize organizational goals. Workload is the allocation of activities among civil servants to accomplish organizational goals based on ability. Civil servants get the amount of works and activities to be performed to achieve objectives and goals of government. Personnel evaluation measures the contribution of a civil servant in total organization achievements.

Performance accountability report of each organization works as a tool for the assurance of organizational accountability. Both organizations and civil servants are liable for the attainment of organizational goals. Organizations shift their goals accomplishment concerned accountability downwards to the civil servants. The burden for the realization of organizational goals goes to civil servants. Authority of organizations allocates the works to civil servants based on the ability through workload analysis, and civil servants are accountable to attain the targeted goals. Civil servants must be conscious about usage of working time properly to finish the ability based jobs within time margin. Management of organizations gives procedures and techniques to civil servants to complete the work for the achievements of organizational goals. The discretionary authority to civil 
servants to perform the work and the recognition of contributions of civil servant to the organizational achievements create a sense of belongingness among civil servants.

\section{Results}

Theory and evidences suggest that personnel evaluation system and organizational goals must have alignment for the enhancement of efficiency and performance of civil servants. Organizational evaluation system helps to produce clear and undistorted the organizational goals. It assists to generate own performance indicators and to formulate own evaluation of civil servants for each organization. Workload analysis of integrated evaluation system supports the authority of the evaluation system to allocate the responsibilities and duties to civil servants in accordance with ability. Alignment strategy inspires authority of the evaluation system to provide clear and unambiguous ways and techniques to civil servants of work to be performed. Authority of the organization pushes regular supervision for the accomplishment of organizational gaols. Such supervision of the authority of the organization compels civil servants for the attainment of organizational goals. Sometimes authority of the organizations gives advises and instructions to induce civil servants completing the targeted jobs properly. In alignment strategy, management of the evaluation system delegates responsibilities to civil servants and recognizes the contributions of civil servants to the organizational achievements. Hence, civil servants take organizational goals as their own goals and this strategy generates a sense of belongingness among civil servants. Alignment strategy secures the accountability of civil servants. Organizational evaluation ensures the accountability of organization and organizations delegate the accountability to the civil servants through alignment strategy. This strategy helps to build teamwork among civil servants. Here, duties and responsibilities of civil servants come from organizational goals and targets of civil servants are common. All civil servants employ themselves to achieve the common goals of organizations.

\section{Discussion}

I need to summarize the features of an effective personnel evaluation system from theories and practical evidences to explore the ineffectiveness of running personnel evaluation system of Bangladesh very distinctively and to explore the ways and techniques to reform. Effective personnel evaluation system must have opportunity to get assistance from organizational evaluation. Organizational evaluation system facilitates civil servants clarifying organizational goals and performance indicators. Effective personnel evaluation system must have a precise law. A precise law gives procedures and techniques as well as creates pressure upon organizations to implement effective evaluation system. To be effective, personnel evaluation system must be implemented internally for each organization. As the functions and responsibilities of diversified ministries are not same, personnel evaluation system of multifarious ministries should not be identical. Own evaluation system of civil servants is conducive to raise effective and operative alignment strategy. It helps civil servants to get undistorted performance metrics. Effective personnel evaluation system must have internal indicators for each organization. Internal indicators of personnel evaluation system assists to strengthen alignment strategy between personnel evaluation and organizational goals. Internal indicators assist in the generation and demarcation of accountability and the supplement of information in regard to organizational goals for the interest of civil servants. Own performance indicators of civil servants support to assess civil servants based on performances. Those indicators assist to launch integration between goals of civil servants and organizations and to recognize the contribution of civil servants in the accomplishment of organizations. Subsequently those also create sense of belongingness among civil servants. Effective personnel evaluation should contain job analysis and workload analysis. Job analysis seeks out the assignments to be executed by civil servants. It facilitates personnel evaluation system to build alignment between targeted goals of civil servants and organizational goals. It recognizes the amount of works of civil servants to be performed to attain organizational goals. Workload analysis assists to distribute jobs among civil servants in accordance with competencies. Job analysis and workload analysis support to employ ability of civil servants. The ability based distribution of works among civil servants ascertains their accountability.

Theory and evidences have proofs that existing personnel evaluation system of Bangladesh has many features of defectiveness and inefficiency. Alignment strategy with organizational goals is absent here. Absence of organizational evaluation has weakened the effectiveness of existing personnel evaluation system. Common personnel evaluation system for all categories of civil servants is another cause of ineffectiveness of the running evaluation system. Though the activities of all civil servants are not same, the performance indicators of performance evaluation of civil servants are common. Job description is non-practiced here. Running evaluation system of civil servants does not practice workload analysis. Bangladesh has no any law regarding the performance evaluation of personnel as well as organizations.

Some reform initiatives are essentials in running performance evaluation of civil servants of Bangladesh to be 
effective and efficient. Bangladesh should implement organizational evaluation to ascertain organizational accountability as well as to get clear and unambiguous organizational goals for civil servants. A law concerning evaluation should be formulated to create compulsory obligation upon ministries to implement evaluation system. Furthermore, a precise law will deliver the ways and techniques to implement effective personnel evaluation system. Government should have personnel evaluation system for each ministry separately. Here, one ministry or institution will be the monitoring authority to supervise the progress of the evaluation system. Bangladesh should exercise job analysis to find the functions and activities of civil servants to be performed to achieve organizational goals. It should implement workload analysis in the evaluation system to allocate functions to civil servants based on their ability. Bangladesh should implement interviews twice or thrice in a year between civil servants and ministries to create stress to complete the work.

Bangladesh has to face some challenges to implement a performance based evaluation system for civil servants. Such performance based personnel evaluation system is effective to make civil servants more accountable. Hence, some civil servants may be reluctant to implement a performance based personnel evaluation system. A good leadership among civil servants can manage all civil servants to accept this new personnel evaluation system through motivation. Promotion and posting of civil servants must be based on performance. To ensure performance based posting and promotion, the top of the civil servants should be free from all kinds of external pressure. To implement effective personnel evaluation system, each ministry needs some technical supports such as a technical team to identify performance indicators, system analyst for data management, and information technology support. To implement this evaluation system, each ministry's goals must be clear and unambiguous. Here, the government goals must be consistent over time for effective personnel evaluation system.

This study has some limitations. Firstly, I have conducted this study based on secondary data. If primary data could be gathered from civil servants of Bangladesh through questionnaire and survey method, the views of civil servants on present personnel evaluation system could be added in this study. Secondly, this study is qualitative, and its inferences are not absolute rather relative. Thirdly, if the number of countries could be increased in the comparative analysis of performance measurement system, the inferences would be stronger. This study has exposed some areas of performance evaluation of civil servants and public sectors for future research in Bangladesh. Firstly, what are the ways and techniques to implement effective evaluation system of civil servants and organizations? Secondly, what are the ways and techniques to find effective performance indicators of civil servants and organizations? Thirdly, what are the ways and techniques to find the clear and unambiguous organizational goals? Fourthly, how does the evaluation system measure the performance of civil servants and organizations?

\section{Acknowledgement}

I would like to express my heartfelt thanks and gratitude to my respectful supervisor Professor Tetsuji Umada, Graduate School of Economics, Yamaguchi University, for his overall support, co-operation, guidance and advice in making progress in the study. Despite his time constant, he provided me with the necessary information without whose support it would have been impossible for me to understand many of the complex issues relating to performance evaluation of civil servants and organizations and preparation of thesis.

\section{References}

Ali Shawkat, A. M. M. (2007). Civil Service Management in Bangladesh: An Agenda for Policy Reform. Dhaka: The University Press Limited.

Annual Confidential Report. (2013, April). Government of the Peoples Republic of Bangladesh. Bangladesh Form No. 290 gha (revised): Annual Confidential Form -1. Bangla version.

Annual Performance Report (APR). Option-2 (June 27, 2012). Performance Based Evaluation System. Government of the Peoples Republic of Bangladesh. Draft version.

Armstrong, M., \& Baron, A. (2005). Managing performance: Performance management in action. London: CIPD Publishing. Retrieved

from http://www.cipd.co.uk/NR/rdonlyres/AC5B3F1D-CA83-4CB2-AD97-9B2333411133/0/Performance_mana gement_in_action.pdf

Auditor General Report, Performance Audit. (2004-05). Performance Management in the Australian Public Service. Australian National Audit Office. Retrieved from http://www.anao.gov.au/uploads/documents/2004-05_Audit_Report_6.pdf

Common Assessment Framework (CAF). (2013). Improving Public Organizations through Self-Assessment: CAF 2013. Resource Centre, European Institute of Public Administration (EIPA) and European Public 
$\begin{array}{llll}\text { Administration } & \text { Network } & \text { Retrieved } & \text { from }\end{array}$ http://www.eupan.eu/files/repository/20121026104955_Newsletter_2012-3_SMALL.pdf

Daley, D. M. (1993). Performance Appraisal As an Aid in Personnel Decisions. American Review of Public Administration, 23, 201-214. http://dx.doi.org/10.1177/027507409302300302

David, O. (August 31, 1993). Chairman, Working Group of Evaluating Team Performance. Interagency Advisory Group Committee on Performance Management and Recognition. A report of working group on evaluating team performance.

Dessler, G. (2005). Human Resource Management (10th ed.). Prentice Hall Inc. New Jersey: Upper Saddle River.

Guidance Manual for Annual Performance Report (APR). (2011). Ministry of Public Administration: Government of Bangladesh. Draft version.

Hellenic (Greek) presidency of the European Union. (June 8-9, 2003). Public Sector Performance Measurement Systems \& Indicators in the EU. Ministry of interior, public administration \& decentralization of Greek. Retrieved from http://www.dgaep.gov.pt/media/0601010000/grecia/PERFORMANCE.pdf

Human Development Centre. (2000). Human Development in South Asia 1999. Islamabad: Human Development Centre. Retrieved from http:/www.mhhdc.org/reports/HDRSA\%202000.pdf

International Labour Organization (ILO), Governing Body. (Geneva, November, 2009). Results-based strategies 2010-15: Human Resources Strategy, Refocusing human resources. GB.306/PFA/12/2, 306th Session. Retrieved from http://www.ilo.org/wcmsp5/groups/public/@ed_norm/@relconf/documents/meetingdocument/wcms_11600 3.pdf

Kazamasa, O. (2005). The Nature and Role of the Civil Service in Japanese Government Decision-Making. Research Development Policy Research Institute, Ministry of Finance, Tokyo, Japan.

Kazuki, H. (2005). The Present Condition of Actual Performance Assessment and Effectiveness Auditing. Government Auditing Review, 12, 85-103.

Kearney, R. C., \& Berman, E. M. (1999). Public Sector Performance: Management Motivation, and Measurement. Colorado: Westview Press, a Member of the Perseus Books Group.

Khan, M. M. (2009). From Government to Governance: Expanding the Horizon of Public Administration to Public Management. Dhaka: The University Press Limited.

Khan M. M. (2005). Bureaucratic Ascendancy: Public Administration in Bangladesh: The First Three Decades. Dhaka: South Asia Publishers.

Lawler, E. E., \& Mohrman, A. M., \& Resnick, S. M. (1984). Performance Appraisal Revisited. Organizational Dynamics, 13(1), 20-35. http://dx.doi.org/10.1016/0090-2616(84)90029-9

Luxembourg Presidency of European Union. (June, 2005). Human Resources management strategies to support organizational changes. Retrieved from http://www.dgaep.gov.pt/media/0601010000/lux/hrmorgchanges.pdf

Masaharu, H. (2003). Japanese Public Administration and its Adaptation to New Public Management. Ritsumeikan Law Review, (20). Retrieved from http://www.ritsumei.ac.jp/acd/cg/law/lex/rlr20/Hori.pdf

Milligan, S. O., Fridell, L., \& Taylor, B. (2006). Implementing an Agency-Level Performance Measurement System: A Guide for Law Enforcement Executives. Police Executive Research Forum. U.S. Retrieved from https://www.ncjrs.gov/pdffiles1/nij/grants/214439.pdf

Ministry of Finance, Finland. (February 5, 2013). Retrieved from https://www.vm.fi/vm/en/12_government_as_employer/index.jsp

Ministry of Internal Affairs and Communications, Japan. (February 5, 2013). Retrieved from http://www.soumu.go.jp/english

Ministry of Public Administration: Government of the Peoples Republic of Bangladesh. Instructions for Officer reported Upon (ORU), Report Initiating Officer (RIO), and Counter Signing Officer (CSO). (December 24, 2012). $\quad$ Retrieved from http://www.mopa.gov.bd/index.php?option=com_content\&task=blogcategory\&id=40\&Itemid=438

Mohammad, A. H. (2012). Performance Appraisal System of Bangladesh Civil Service: An Analysis of Its Efficacy. International Public Management Review, 13(1). 
Monem, M., Osman, F., \& Nuruzzaman, M. (2009). Performance Management. The Project for Developing the Training Capacity of the Bangladesh Civil Service Administration Academy. Sponsored by KOICA, Korea.

National Personnel Authiry. (2013). Outline of the Ordinance Concerning the Standards and Methods of Personnel Appraisal System. Retrieved from http://ssl.jinji.go.jp/en/measure/npasystem.html

Newstrom, J. W., \& Davis, K. (1993). Organisational behaviour: Human behaviour at work. New York: McGraw-Hill.

OECD. (February, 2011). Review on Evaluation and Assessment Frameworks for Improving School Outcomes: Country Background Report: LUXEMBOURG: Agency for the Development of Quality in Schools (ADQS). Retrieved from http://www.oecd.org/edu/school/LuxembourgCBR.pdf

Peter, S. (1990). The Use of Performance Indicators in the Public Sector. Journal of the Royal Statistics Society $\begin{array}{llllll}\text { Series } & \text { (Statistics } & \text { in } & \text { Society), } & 153 . & \text { Retrieved }\end{array}$ http://gent.uab.cat/diego_prior/sites/gent.uab.cat.diego_prior/files/Smith_jrss_1990_153_01.pdf

Peter, S. (2006). Measuring Outcome in the Public Sector. New York: Taylor \& Francis.

Poister, T. H. (2003). Measuring performance in public and nonprofit organizations. San Francisco: Published by Jossey-Bass.

Profile of National Public Employees. (2011). On the Personnel Administration Carried out By the National Personnel Authority (NAP) of Japan. National Personnel Authority. Tokyo. Retrieved from http://ssl.jinji.go.jp/en/infonpa/profile.pdf

Public Administration Reform Commission (PARC). (2000). Public Administration for 21st Century: Report of the PARC, 1. Dhaka: PARC.

Public Administration Reform Commission (PARC). (2000). Public Administration for 21st Century: Report of the PARC, 2. Dhaka: PARC.

Public Administration Reform Commission (PARC). (2000). Public Administration for 21st Century: Report of the PARC, 3. Dhaka: PARC.

Ritter, S. ( March 5, 2013). Structure of the Civil and Public Services: In the Member and Accession States of the European Union. Published by the Austrian Federal Chancellery, Directorate General III - Civil Service and Administrative Reform, A-1010 Vienna, Hohenstaufengasse 3. Retrieved from http://www.dgaep.gov.pt/media/0601010000/austria/Structure\%20of\%20the\%20Civil.pdf

Robb, D. A. J., Nanni, T. J., \& Vollmann, E. (1990). The New Performance Challenge: Measuring operations for world-class competition. New York: Business One Irwin.

Roland, F. S., Frank, H. M., \& Verbeeten. (2009). The use of performance measurement systems in the public sector: effects on performance. Nyenrode Business University and RSM Erasmus University.

Rossi, P. H., Lipsey, M. W., \& Freeman, H. E. (2004). Evaluation: A Systematic Approach. California: Sage Publication Inc.

Rynes, S., Brown, K., \& Colbert, A. (2002). Seven common misconceptions about human resource practice: Research findings versus practitioner beliefs. Academy of Management Executive, 16(3). http://dx.doi.org/10.5465/AME.2002.8540341

Sanders, J. R. (1994). The Program Evaluation Standards: How to Assess Evaluations of Education Programs. California: Sage Publication Inc.

Sarker, A. E. (2004). Adminstrative Reform in Bangladesh: Three decades of Failure. International Public Management Journal, 7(3), 365-384.

Siddiqui, U. K. (2006). Towards Good Governance in Bangladesh: Fifty Unpleasant Essays. Dhaka: The University Press Limited.

Somerick, N. M., (1993). Strategies for Improving Employee Relations by Using Performance Appraisals More Effectively. Public Relation Quarterly, 38(3), 37-39.

Thornburg, L. (1991). Performance Measures that Work. HR Magazine, 35-38.

Mark, T., \& David, H. (1997). Governance, Administration \& Development: Making the State Work. Virginia: Kumarian Press.

Uusikylä, P., \& Virtanen, P. (1999). Public Sector Performance Contracting in Finland. Public Management 
Department, Finnish Ministry of Finance. Retrieved from http://www.oecd.org/gov/budgeting/1902738.pdf

Williams, P. (2002). The Competent Boundary Spanner. Public Administration. New Jersey: Blackwell Publishers Ltd.

World Bank. (2010). Worldwide Governance Indicators-2010. Development Research Group. Retrieved from http://info.worldbank.org/governance/wgi/index.asp

Zafarullah, H., Khan, M. M., \& Rahman, M. H. (1997). Civil Service Systems: Bangladesh: Paper prepared for the conference on Civil Service Systems in Comparative Perspective, School of Public and Environmental Affairs, Indiana University, Bloomington, Indiana, 5-8 April 1997.

\section{Note}

Note 1. Percentile Ranks: Percentile ranks indicate the percentage of countries worldwide that score below each country. For example, a country with a percentile rank of 70 means that such country scores above 70 percent of the countries in the world, while scoring below the other 30 percent of (better scoring) countries.

\section{Copyrights}

Copyright for this article is retained by the author(s), with first publication rights granted to the journal.

This is an open-access article distributed under the terms and conditions of the Creative Commons Attribution license (http://creativecommons.org/licenses/by/3.0/). 